\title{
Importance of sequential herbicide application in the control of Elephantopus mollis
}

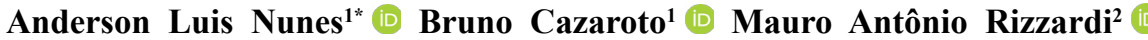 \\ Mário Antonio Bianchi ${ }^{3}$ (iD Leandro Oliveira da Costa $^{4}$ (iD Aldo Merotto Junior $^{5}$ (iD
}

\author{
${ }^{1}$ Curso de Agronomia, Instituto Federal do Rio Grande do Sul (IFRS), 99170-000, Sertão, RS, Brasil. E-mail: anderson.nunes@sertao.ifrs.edu.br. \\ ${ }^{*}$ Corresponding author. \\ ${ }^{2}$ Programa de Pós-graduação em Agronomia, Universidade de Passo Fundo (UPF), Passo Fundo, RS, Brasil. \\ ${ }^{3}$ Cooperativa Central Gaúcha Ltda (CCGL Tec), Cruz Alta, RS, Brasil. \\ ${ }^{4}$ Curso de Agronomia, Instituto Federal Farroupilha (IFFar), Júlio de Castilhos, RS, Brasil. \\ ${ }^{5}$ Programa de Pós-graduação em Fitotecnia, Universidade Federal do Rio Grande do Sul (UFRGS), Porto Alegre, RS, Brasil.
}

ABSTRACT: Elephantopus mollis, popularly known as elephant paw or sussuaiá, is a species that has recently emerged as a weed affecting grain crops. This study aimed to evaluate the differential sensitivity of biotypes of E. mollis obtained from agricultural and nonagricultural areas and to determine the best combinations of herbicides applied at different stages of development for controlling this species. Three experiments were conducted. In the differential sensitivity experiment, 10 herbicides were used in 2 biotypes in 2 stages of development. The dose-response experiment was conducted using 8 doses of 7 herbicides. The field experiment was conducted in an area with weed issues to validate the results of previous experiments. The biotype from the agricultural area showed lower sensitivity to herbicides than the biotype from the nonagricultural area. The contact herbicides initially presented better control; however, the weed shortly showed re-growth due to the presence of buds in the plant crown. Isolated application of 2.4-D amine at doses between 1005 and $1675 \mathrm{~g}$ a.e. ha $\mathrm{a}^{-1}$ demonstrated $25 \%$ control. When 2,4-D amine was followed by paraquat application (400 $\mathrm{g}$ a.i. ha $\left.\mathrm{a}^{-1}\right)$, the control observed was between $51 \%$ and $68 \%$. The best treatment for the control of completely developed weeds is 2,4-D amine + glyphosate mixture $\left(1340+1080 \mathrm{~g}\right.$ a.e. ha $\left.\mathrm{g}^{-1}\right)$, followed by sequential paraquat application.

Key words: elephant paw, Sussuaiá, 2,4-D amine, glyphosate.

A importância da aplicação sequencial no controle de Elephantopus mollis

RESUMO: Popularmente conhecida como pata de elefante ou sussuaiá, Elephantopus mollis, é uma espécie que recentemente surgiu como uma planta daninha em lavouras de cultivos de grãos. Objetivou-se com este estudo avaliar a sensibilidade diferencial de biótipos de E. mollis oriundos de áreas agrícolas e não agrícolas e determinar as melhores combinações de herbicidas aplicados em diferentes estádios de desenvolvimento para o controle desta espécie. Foram realizados três experimentos. No experimento de sensibilidade diferencial foram utilizados dez herbicidas em dois biótipos em duas fases de desenvolvimento. O experimento de dose resposta foi conduzido com oito doses de sete herbicidas. O experimento a campo foi realizado em uma área que apresenta problemas com a planta daninha para validar os resultados dos experimentos anteriores. O biótipo oriundo de área agrícola apresentou menor sensibilidade aos herbicidas quando comparado ao biótipo oriundo de área não agrícola. Os herbicidas de contato inicialmente apresentam controle superior, mas logo a planta apresenta rebrote em função de gemas presentes no colo da planta. A aplicação isolada de 2,4-D com doses entre 1005 e $1675 \mathrm{~g}$ e.a ha-1 possui controle de $25 \%$. Quando o 2,4-D é seguido da aplicação de paraquat (400 $\mathrm{g}$ i.a ha $\mathrm{h}^{-1}$ ) o controle passa a ser entre 51 e $68 \%$. O melhor tratamento para o controle de plantas desenvolvidas é a mistura de 2,4-D + glyphosate $\left(1340+1080 \mathrm{~g}\right.$ e.a ha $\left.\mathrm{a}^{-1}\right)$ com aplicação sequencial de paraquat.

Palavras-chave: pata de elefante, Sussuaiá, 2,4-D amina, glyphosate.

\section{INTRODUCTION}

The soybean crop, one of the main crops cultivated in Brazil, is the principal commodity when it comes to generating foreign exchange income for the country. However, there are obstacles limiting productivity, thereby causing losses. These include interference caused by weeds in the initial stages of development, with losses as high as 95\% (BARNES et al., 2018) and rendering harvesting unfeasible in extreme cases. Weeds, having mechanisms that enable them to thrive in adverse environments, can reduce productivity as well as damage the crop quality, leading to uneven maturation and loss of grain quality, or can act as hosts for pests or diseases that may eventually affect the crop (OLIVEIRA JUNIOR et al., 2011).

With the introduction of glyphosateresistant soybean and simplification of weed control, which essentially involves the exclusive use of 
this herbicide, cases of glyphosate tolerance and resistance have emerged, creating one of the major issues encountered in soybean, corn, and cotton crop cultivation currently. It is becoming increasingly difficult to control the weed Elephantopus mollis (elephant's paw or sussuaiá), which was previously absent in agricultural production systems (BALBINOT, 2016). E. mollis, belonging to the family Asteraceae is a perennial herbaceous plant with medicinal potential (WU et al., 2017) and comprises a slightly lignified base and extremely short branches (BUNWONG et al., 2014). It is native to the American continent and is found throughout Brazil (FRANCISCO et al., 2019). Flowers are purplish, arranged in terminal and axillary capitula and protected by bracts (BUNWONG et al., 2014). New leaves bud underneath the existing leaves, which indicates that the meristems are protected, thereby enabling the weed to resume growth after a period of stress. Its perpetuation in the field mainly occurs via rhizomes, which explain its occurrence in coppices within the area.

Difficulties in controlling this weed are currently being reported. The herbicide glyphosate does not cause injury to the point of reducing the population. Moreover, considering that E. mollis ceases its metabolism during the cold period, herbicides used on winter crops do not impact the weed's development. Pre-seeding desiccation using contact herbicides, such as paraquat, even at high doses, only causes the weed to present necrosis and lose turgescence for a few days before recovering growth via new shoots.

The presence of a xylopodium at the base of E. mollis may be the structure responsible for the weed's ability to produce new shoots because contact herbicides do not reach this site. In Brazil, there are no records of any commercial products or any concrete studies regarding the control of E. mollis; therefore, there is a demand for studies on feasible means of controlling it. This study aimed to evaluate the differential sensitivity of biotypes of E. mollis from agricultural and nonagricultural areas and to determine the best combinations of herbicides applied at different stages of development to control this species.

\section{MATERIALS AND METHODS}

Three experiments were conducted to determine a method for the control of E. mollis. The differential sensitivity and dose-response experiments were conducted in a greenhouse in a controlled environment in the municipality of Sertão-

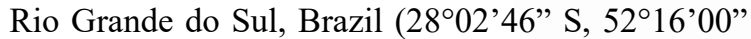
$\mathrm{W})$ in 2016. The differential sensitivity experiment was conducted between the months of March and July 2016, in 2-L vessels filled with substrate. The dose-response experiment was conducted between September and December of the same year in $0.5-\mathrm{L}$ vessels. For the two experiments conducted in the greenhouse, the mean temperatures were $22.3{ }^{\circ} \mathrm{C}$ $\pm 3.2{ }^{\circ} \mathrm{C}$ and $25.8{ }^{\circ} \mathrm{C} \pm 4.1{ }^{\circ} \mathrm{C}$, and the relative air humidity was $73.2 \% \pm 6.6 \%$ and $62.0 \% \pm 7.2 \%$. The field experiment was conducted between September and November 2017 in a grain production area having E. mollis presence at Fazenda Cazaroto, São João, in the municipality of Sertão-Rio Grande do Sul, Brazil (28॰03'77' S, 52²5'19” W).

In the differential sensitivity experiment, a completely randomized experimental design having a trifactorial arrangement $(2 \times 2 \times 11)$ with four replications was followed. The first factor comprised two biotypes of E. mollis - one from an agricultural area with grain cultivation where the experiment was subsequently conducted in the field and the other from a nonagricultural area (lawn). The second factor comprised two stages of plant development — vegetative (3-4 leaves) and reproductive (flowering). The third factor comprised the application of 10 post-emergent herbicidal treatments along with the control (Table 1).

The dose-response experiment was conducted as four repetitions of the sprinkling of 8 doses of 7 herbicides or mixtures (Table 2). For the field experiment, the experimental design involved randomized blocks with subdivided plots, and four replications were employed. The main plot was comprised sprinkling 8 treatments of herbicides, either individual herbicide or mixtures, along with the control (Table 1), or the subplot included sequential or non-sequential sprinkling of the herbicide paraquat (400 g a.i. ha ${ }^{-1}$ ) at 28 days after the first application.

In all three experiments, the herbicidal treatments were applied using a $200 \mathrm{kPa} \mathrm{CO}_{2}$-pressurized sprayer, providing $180 \mathrm{~L} \mathrm{ha}^{-1}$, and Teejet XR11001 tips. Visual control evaluations in E. mollis were conducted via a visual examination to determine the effect of the herbicides, using a scale of $0-100$, where 0 indicates the absence of symptoms and 100 indicates total weed control (FRANS \& CROWLEY, 1986).

The data obtained from the field and differential sensitivity experiments were analyzed using the Shapiro-Wilk normality test to determine the need for data transformation. When necessary, data were transformed into "root of $x+1$ " to stabilize variances. Data were assessed using analysis of variance, followed by a comparison of means using 
Table 1 - Relationship among herbicides, doses, concentrations/formulations, and manufacturers used in the field and differential sensitivity experiments (IFRS, Sertão-RS, 2017).

\begin{tabular}{|c|c|c|c|c|}
\hline Common names & Trade name & Rates g a.i. ha ${ }^{-1}$ & $\begin{array}{l}\text { Concentration/ } \\
\text { formulation }\end{array}$ & Manufacturer \\
\hline Untreated (control) & -- & -- & -- & -- \\
\hline Paraquat (Prqt) & Orbit & 600 & $200 \mathrm{SL}$ & Sinon \\
\hline Glyphosate (Gly) & Roundup WG (R WG) & $1080^{1}$ & $720 \mathrm{WG}$ & Bayer \\
\hline Saflufenacil (Saf) & Heat & 35 & $700 \mathrm{WG}$ & Basf \\
\hline Pyraflufen & Kabuki & 8,75 & $25 \mathrm{EC}$ & Nichino \\
\hline 2,4-D amine $(2,4-\mathrm{D})$ & Aminol 806 & $1340^{1}$ & $806 \mathrm{~S}$ & Adama \\
\hline Chlorimuron & Classic & 30 & $250 \mathrm{WG}$ & Corteva \\
\hline Glufosinate & Finale & 400 & $200 \mathrm{SL}$ & Bayer \\
\hline Gly + Saf & R WG + Heat & $1080^{1}+35$ & $720 \mathrm{WG}+700 \mathrm{WG}$ & Bayer + Basf \\
\hline Gly + pyraflufen & R WG + Kabuki & $1080^{1}+8,75$ & $720 \mathrm{WG}+25 \mathrm{EC}$ & Bayer + Nichino \\
\hline Gly + chlorimuron & R WG + Classic & $1080^{1}+30$ & $720 \mathrm{WG}+250 \mathrm{WG}$ & Bayer + Corteva \\
\hline \multicolumn{5}{|c|}{ 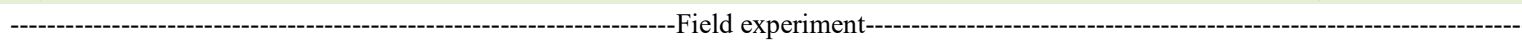 } \\
\hline Untreated (control) & -- & -- & -- & -- \\
\hline Gly / Prqt & R WG / Orbit & $1080^{1} / 400$ & $720 \mathrm{WG} / 200 \mathrm{SL}$ & Bayer / Sinon \\
\hline Gly + Saf/Prqt & R WG + Heat / Orbit & $1080^{1}+35 / 400$ & $\begin{array}{c}720 \mathrm{WG}+700 \mathrm{WG} / \\
200 \mathrm{SL}\end{array}$ & Bayer + Basf / Sinon \\
\hline Gly + 2,4-D/Prqt & $\mathrm{R} \mathrm{WG}+$ Aminol / Orbit & $\begin{array}{c}1080^{1}+1340^{1} / \\
400\end{array}$ & $\begin{array}{c}720 \mathrm{WG}+806 \mathrm{~S} / \\
200 \mathrm{SL}\end{array}$ & Bayer + Adama / Sinon \\
\hline 2,4-D/Prqt & Aminol / Orbit & $670^{1} / 400$ & $806 \mathrm{~S} / 200 \mathrm{SL}$ & Adama / Sinon \\
\hline 2,4-D/Prqt & Aminol/ Orbit & $1005^{1} / 400$ & $806 \mathrm{~S} / 200 \mathrm{SL}$ & Adama / Sinon \\
\hline 2,4-D/Prqt & Aminol/ Orbit & $1340^{1} / 400$ & $806 \mathrm{~S} / 200 \mathrm{SL}$ & Adama / Sinon \\
\hline 2,4-D/Prqt & Aminol/ Orbit & $1675^{1} / 400$ & $806 \mathrm{~S} / 200 \mathrm{SL}$ & Adama / Sinon \\
\hline
\end{tabular}

${ }^{1} \mathrm{~g}$ a.e. $\mathrm{ha}^{-1}$.

Abbreviations: $\mathrm{SL}=$ soluble concentrate; $\mathrm{WG}=$ water-dispersible granule; $\mathrm{EC}=$ emulsifiable concentrate; $\mathrm{S}=$ solution.

Tukey test $(p \leq 0.05)$, when the $F$ test of the analysis of variance was significant $(p \leq 0.05)$.

For the dose-response experiment, regressions were performed using the SigmaPlot program, version 12.5 , establishing the ratio between the percentage of the control and dose of the herbicide used. Nonlinear regression models were adjusted for the response variables using the three-parameter logistic model, according to STREIBIG (1988):

$y=\frac{a}{\left[1+\left(\frac{x}{b}\right)^{c}\right]}$

where, " $y$ " is the control percentage; " $x$ " is the herbicide dose in $\mathrm{g}$ a.i. ha ${ }^{-1}$; and "a", "b" and "c" are parameters estimated by the equation, where "a" is the amplitude between the maximum and minimum point of the variable; " $\mathrm{b}$ " is the dose corresponding to $50 \%$ weed control $\left(\mathrm{C}_{50}\right)$; and "c" is the slope of the curve around " $b$ ". $\mathrm{C}_{80}$ and $\mathrm{C}_{95}$ values were determined using the inverse equation, according to CARVALHO et al. (2005): $x=b\left(\left|\frac{a}{y}-1\right|\right)^{\frac{1}{c}}$

\section{RESULTS AND DISCUSSION}

\section{Differential sensitivity experiment}

Only the interactions "biotypes $x$ herbicides" and "stage $\times$ herbicides" were significant (Tables 3 and 4, respectively). Regarding biotypes, the lawn biotype showed higher sensitivity to herbicides than the agricultural area biotype (Table 3). Chlorimuron did not exhibit satisfactory control in either of these biotypes. The herbicide pyraflufen, a PROTOX inhibitor, was more efficient in the nonagricultural areas area biotype. The higher sensitivity of the lawn biotype than the agricultural area biotype was expected because the recurrent application of herbicides having the same mechanism of action in the agricultural area results in weed 
Table 2 - Relationship among herbicides, doses, concentrations, and formulations used in the dose-response experiment (IFRS, SertãoRS, 2017).

\begin{tabular}{|c|c|c|c|c|c|c|c|c|}
\hline \multirow[t]{2}{*}{ Common names } & \multirow[t]{2}{*}{ Mechanism of action } & \multicolumn{7}{|c|}{ 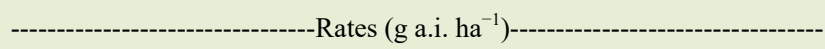 } \\
\hline & & $1 / 8$ & $1 / 4$ & $1 / 2$ & $1 \mathrm{X}$ & $2 X$ & $4 \mathrm{X}$ & $8 X$ \\
\hline Paraquat & PS I Electron Diversion & 75 & 150 & 300 & 600 & 1200 & 2400 & 4800 \\
\hline Glufosinate & In. of Glutamine Synthetase & 75 & 150 & 300 & 600 & 1200 & 2400 & 4800 \\
\hline Pyraflufen & Inhibition of PROTOX & 1,09 & 2,18 & 4,38 & 8,75 & 17,5 & 35 & 70 \\
\hline Saflufenacil & Inhibition of PROTOX & 4,38 & 8,75 & 17,5 & 35 & 70 & 140 & 280 \\
\hline Chlorimuron & Inhibition of ALS & 3,75 & 7,5 & 15 & 30 & 60 & 120 & 240 \\
\hline Glyphosate (Gly) & Inhibition of EPSPS & $135^{1}$ & 270 & 540 & 1080 & 2160 & 4320 & 8640 \\
\hline Pyraflufen + Gly & PROTOX + EPSPS & $1,09^{2}$ & 2,18 & 4,38 & 8,75 & 17,5 & 35 & 70 \\
\hline Saflufenacil + Gly & PROTOX + EPSPS & $4,38^{2}$ & 8,75 & 17,5 & 35 & 70 & 140 & 280 \\
\hline Chlorimuron + Gly & ALS + EPSPS & $3,75^{2}$ & 7,5 & 15 & 30 & 60 & 120 & 240 \\
\hline 2,4-D amine & Auxin mimics & $167,5^{1}$ & 335 & 670 & 1340 & 2680 & 5360 & 10720 \\
\hline
\end{tabular}

${ }^{1}$ g a.e. ha ${ }^{-1} \cdot{ }^{2}$ In all doses of the treatments "Pyraflufen + Gly", "Saflufenacil + Gly" and "Chlorimuron + Gly", glyphosate was added at 1080 g a.e. ha ${ }^{-1}$.

Abbreviations: SL, soluble concentrate WG, water-dispersible granule; EC, emulsifiable concentrate; S, solution; Conc, Concentration.

population with greater resistance to these herbicides (Yu et al., 2013).

Regarding to the stage of plant development, the behavior of the herbicides was similar in both phases (Table 4). For the herbicides glyphosate, pyraflufen, and glufosinate, at 57 days after application (DAA), the control levels were $31 \%, 25 \%$, and $20 \%$ higher in the vegetative phase than that in the reproductive phase. With plant development, the absorption and translocation of herbicides become increasingly limited and the mechanisms of detoxification become increasingly effective (OLIVEIRA JUNIOR et al., 2011). However, some herbicides that control the species of the Asteraceae family did not present satisfactory control in the vegetative phase of E. mollis (Table 4). This demonstrates that this species may present barriers to absorption and translocation as well as elaborate mechanisms of detoxification of herbicides and their effects in the vegetative phase itself.

Regarding the efficiency of the herbicides in this experiment, in the evaluations performed at 14 DAA, the contact herbicides and mixtures showed the best results (Tables 3 and 4). In the evaluation at 57 DAA, the contact herbicides began losing efficiency owing to plant regrowth, and systemic herbicides showed better performance. E. mollis contains rhizome-developing activity and is capable of developing shoots from the existing leaves.
Contact herbicides are unable to reach the region where the shoots occur. In the final evaluation at 81 DAA, the best results were obtained in the treatments using systemic herbicides that showed a good mobility within the plant, such as the combination of 2,4-D amine and glyphosate with saflufenacil or chlorimuron. The exception was the herbicide glufosinate, which presented medium mobility within the plant and resulted in high control at 81 DAA.

\section{Dose-response experiment}

The visual control data fit the threeparameter logistic model. $\mathrm{R}^{2}$ values were between 0.97 and 0.99 , and the significance of the adjustments, denoted by $\mathrm{p}$-value was $<0.0001$. The dose required for the control of $50 \%$ of the population $\left(\mathrm{C}_{50}\right)$ and that required for the control of $80 \%$ and $95 \%$ of the population $\left(\mathrm{C}_{80}\right.$ and $\left.\mathrm{C}_{95}\right)$ were determined via model adjustment and using the inverse equation, respectively. The $\mathrm{C}_{80}$ and $\mathrm{C}_{95}$ values are important from a practical viewpoint. The $\mathrm{C}_{80}$ value is the dose needed to obtain $80 \%$ control, which is the minimum acceptable control. However, in cases where a new instance of resistance or tolerance is being observed, it is considered that the biotype should be eradicated to prevent the spread of the issue. Therefore, $\mathrm{C}_{95}$ values were also evaluated for evaluation of the results. $\mathrm{C}_{80}$ and $\mathrm{C}_{95}$ values will be compared with the maximum-recommended dose for the control of 
Table 3 - Visual control (\%) of Elephantopus mollis at 14, 35, 57, and 81 days after application (DAA) as a function of the interaction between biotypes (agricultural area and non-agricultural area) and herbicides.

\begin{tabular}{|c|c|c|c|c|c|c|c|c|c|c|c|c|c|c|c|c|c|}
\hline \multirow{2}{*}{\multicolumn{2}{|c|}{ Herbicide }} & \multicolumn{4}{|c|}{---------14 DAA-------- } & \multicolumn{4}{|c|}{-----------35 DAA---------- } & \multicolumn{4}{|c|}{-----------57 DAA----------- } & \multicolumn{4}{|c|}{------------81 DAA------------- } \\
\hline & & \multicolumn{2}{|c|}{--Lawn-- } & \multicolumn{2}{|c|}{--Crop-- } & \multicolumn{2}{|c|}{---Lawn--- } & \multicolumn{2}{|c|}{---Crop--- } & \multicolumn{2}{|c|}{---Lawn--- } & \multicolumn{2}{|c|}{----Crop---- } & \multicolumn{2}{|c|}{---Lawn--- } & \multicolumn{2}{|c|}{-----Crop----- } \\
\hline Paraquat & & 71 & $\mathrm{aBC}^{1}$ & 48 & $\mathrm{bB}$ & 76 & $\mathrm{aA}$ & 66 & $\mathrm{aAB}$ & 31 & $\mathrm{aCD}$ & 11 & $\mathrm{bCD}$ & 35 & $\mathrm{aBCD}$ & 30 & $\mathrm{aDEF}$ \\
\hline Glyphosate & & 38 & $\mathrm{aDE}$ & 18 & $\mathrm{bC}$ & 8 & $\mathrm{aDE}$ & 18 & $\mathrm{aC}$ & 89 & $\mathrm{aA}$ & 42 & $\mathrm{bBC}$ & 78 & $\mathrm{aA}$ & 49 & bBCDE \\
\hline Saflufenacil & & 93 & $\mathrm{aA}$ & 96 & $\mathrm{aA}$ & 67 & $\mathrm{aAB}$ & 85 & $\mathrm{aA}$ & 70 & $\mathrm{aAB}$ & 68 & $\mathrm{aAB}$ & 65 & $\mathrm{aAB}$ & 68 & $\mathrm{aABCD}$ \\
\hline Pyraflufen & & 28 & $\mathrm{aEF}$ & 8 & $\mathrm{bC}$ & 46 & $\mathrm{aABCD}$ & 27 & $\mathrm{aBC}$ & 44 & $\mathrm{aBC}$ & 1 & $\mathrm{bD}$ & 54 & $\mathrm{aABC}$ & 4 & $\mathrm{bF}$ \\
\hline 2,4-D amine & & 12 & $\mathrm{aFG}$ & 11 & $\mathrm{aC}$ & 10 & aCDE & 10 & $\mathrm{aC}$ & 92 & $\mathrm{aA}$ & 91 & $\mathrm{aA}$ & 92 & $\mathrm{aA}$ & 97 & $\mathrm{aA}$ \\
\hline Chlorimuron & & 5 & $\mathrm{aG}$ & 2 & $\mathrm{aC}$ & 3 & $\mathrm{aE}$ & 15 & $\mathrm{aC}$ & 8 & $\mathrm{aD}$ & 11 & $\mathrm{aCD}$ & 19 & $\mathrm{aCD}$ & 20 & $\mathrm{aEF}$ \\
\hline Glufosinate & & 90 & $\mathrm{aAB}$ & 88 & $\mathrm{aA}$ & 79 & $\mathrm{aA}$ & 71 & $\mathrm{aA}$ & 93 & $\mathrm{aA}$ & 87 & $\mathrm{aA}$ & 90 & $\mathrm{aA}$ & 79 & $\mathrm{aABC}$ \\
\hline $\begin{array}{l}\text { Glyphosate } \\
\text { saflufenacil }\end{array}$ & + & 99 & $\mathrm{aA}$ & 98 & $\mathrm{aA}$ & 75 & $\mathrm{aA}$ & 96 & $\mathrm{aA}$ & 98 & $\mathrm{aA}$ & 90 & $\mathrm{aA}$ & 90 & $\mathrm{aA}$ & 90 & $\mathrm{aAB}$ \\
\hline $\begin{array}{l}\text { Glyphosate } \\
\text { pyraflufen }\end{array}$ & + & 54 & $\mathrm{aCD}$ & 49 & $\mathrm{aB}$ & 52 & $\mathrm{aABC}$ & 65 & $\mathrm{aAB}$ & 92 & $\mathrm{aA}$ & 50 & $\mathrm{bB}$ & 93 & $\mathrm{aA}$ & 48 & bCDE \\
\hline $\begin{array}{l}\text { Glyphosate } \\
\text { chlorimuron }\end{array}$ & & 18 & $\mathrm{aEFG}$ & 12 & $\mathrm{aC}$ & 3 & $\mathrm{aE}$ & 0 & $\mathrm{aC}$ & 95 & $\mathrm{aA}$ & 60 & $\mathrm{bAB}$ & 83 & $\mathrm{aA}$ & 85 & $\mathrm{aABC}$ \\
\hline $\begin{array}{l}\text { Untreated } \\
\text { (control) }\end{array}$ & & 0 & $\mathrm{aG}$ & 0 & $\mathrm{aC}$ & 0 & $\mathrm{aE}$ & 0 & $\mathrm{aC}$ & 0 & $\mathrm{aD}$ & 0 & $\mathrm{aD}$ & 0 & $\mathrm{aD}$ & 0 & $\mathrm{aF}$ \\
\hline
\end{tabular}

${ }^{1}$ Uppercase letters denote the comparison of herbicide treatments within the same biotype (column), and lowercase letters denote the comparison of herbicide treatments within different biotypes (row). Means followed by the same letter, either lowercase or uppercase, are not significantly different according to the Tukey test at 0.05 .

dicotyledonous weeds in the pre-sowing of soybean. In the absence of this specific information, the maximum-recommended dose for weed control in the soybean crop was used, and in the absence of that information, the maximum-recommended dose for any weed in any annual crop was used (Table 5).

Paraquat caused significant injury in the initial evaluations. However, the weed presented considerable re-growth and $\mathrm{C}_{80}$ and $\mathrm{C}_{95}$ values were above the maximum-recommended dose, based on the evaluation performed at 35 DAA (Table 5). Isolated glyphosate, chlorimuron, and glyphosate + chlorimuron applications demonstrated low visual weed control. According to the parameter "a" of the equation, which estimates the amplitude between the minimum and maximum control, it was verified that it $100 \%$ control of the weed population cannot be achieved despite using doses 8 times the recommended dose. The herbicide 2,4-D amine presented a slow evolution of symptoms observed in the weed. This herbicide was effective against $E$. mollis only at 81 DAA when the dose for $\mathrm{C}_{80}$ was $636 \mathrm{~g}$ a.e. $\mathrm{ha}^{-1}$. However, $\mathrm{C}_{95}$ value was above the maximum-recommended dose, demonstrating the need to perform sequential applications using other herbicides to complement the control. The herbicide glufosinate presented similar behavior to that of systemic herbicides, with a gradual reduction in $\mathrm{C}_{80}$ and $\mathrm{C}_{95}$ values. At $81 \mathrm{DAA}, \mathrm{C}_{80}$ and $\mathrm{C}_{95}$ values were below the maximum-recommended doses.

Isolated pyraflufen and saflufenacil applications showed the same behavior as that shown by the herbicide paraquat, enabling an elevated re-growth of the weed. However, when combined with glyphosate, $\mathrm{C}_{80}$ values were below the maximum-recommended dose. This demonstrates the synergistic effect of the combination of glyphosate with pyraflufen or saflufenacil; in their isolated applications, glyphosate and these herbicides showed limited control over time. The synergistic effect of these herbicides with glyphosate is caused by the increase in the absorption and translocation of both herbicides in the plant, thereby reaching a higher dose at the site of action and resulting in better control (FIGUEIREDO, 2015).

\section{Field experiment}

Results of the field experiment showed that isolated glyphosate application presented visual control of $<10 \%$ until 21 DAA, reaching $16 \%$ at 
Table 4 - Visual control (\%) of Elephantopus mollis at 14, 35, 57, and 81 days after application (DAA) as a function of the interaction between stages (vegetative and reproductive) and herbicides.

\begin{tabular}{|c|c|c|c|c|c|c|c|c|c|c|c|c|c|c|c|c|}
\hline \multirow{3}{*}{$\begin{array}{l}\text { Herbicide } \\
\text { Paraquat }\end{array}$} & \multicolumn{4}{|c|}{-----------14 DAA------------ } & \multicolumn{4}{|c|}{--------35 DAA------- } & \multicolumn{4}{|c|}{--------------57 DAA------------- } & \multicolumn{4}{|c|}{------------81 DAA------------ } \\
\hline & \multicolumn{2}{|c|}{-----Veg.----- } & \multicolumn{2}{|c|}{---Rep.--- } & \multicolumn{2}{|c|}{--Veg.-- } & \multicolumn{2}{|c|}{--Rep.-- } & \multicolumn{2}{|c|}{-----Veg.----- } & \multicolumn{2}{|c|}{----Rep.---- } & \multicolumn{2}{|c|}{-----Veg.----- } & \multicolumn{2}{|c|}{---Rep.--- } \\
\hline & 64 & $\mathrm{aB}^{1}$ & 55 & $\mathrm{aB}$ & 68 & ns & 73 & ns & 29 & $\mathrm{aCDE}$ & 12 & $\mathrm{aC}$ & 48 & $\mathrm{aBCD}$ & 17 & $\mathrm{bCD}$ \\
\hline Glyphosate & 31 & $\mathrm{aCD}$ & 24 & $\mathrm{aC}$ & 21 & & 5 & & 82 & $\mathrm{aAB}$ & 50 & $\mathrm{bB}$ & 85 & $\mathrm{aAB}$ & 42 & $\mathrm{bBC}$ \\
\hline Saflufenacil & 95 & $\mathrm{aA}$ & 94 & $\mathrm{aA}$ & 76 & & 75 & & 73 & $\mathrm{aAB}$ & 65 & $\mathrm{aAB}$ & 67 & $\mathrm{aABC}$ & 67 & $\mathrm{aAB}$ \\
\hline Pyraflufen & 28 & $\mathrm{aCDE}$ & 7 & $\mathrm{bCD}$ & 45 & & 28 & & 35 & $\mathrm{aCD}$ & 10 & $\mathrm{bC}$ & 38 & $\mathrm{aCDE}$ & 21 & $\mathrm{aCD}$ \\
\hline 2,4-D amine & 8 & $\mathrm{aEF}$ & 14 & $\mathrm{aCD}$ & 10 & & 10 & & 94 & $\mathrm{aA}$ & 88 & $\mathrm{aA}$ & 92 & $\mathrm{aA}$ & 97 & $\mathrm{aA}$ \\
\hline Chlorimuron & 5 & $\mathrm{aF}$ & 2 & $\mathrm{aD}$ & 15 & & 3 & & 14 & $\mathrm{aDE}$ & 4 & $\mathrm{aC}$ & 16 & $\mathrm{aDE}$ & 23 & $\mathrm{aCD}$ \\
\hline Glufosinate & 88 & $\mathrm{aA}$ & 89 & $\mathrm{aA}$ & 86 & & 84 & & 100 & $\mathrm{aA}$ & 80 & $\mathrm{bAB}$ & 100 & $\mathrm{aA}$ & 69 & $\mathrm{bAB}$ \\
\hline $\begin{array}{l}\text { Glyphosate + } \\
\text { saflufenacil }\end{array}$ & 98 & $\mathrm{aA}$ & 98 & $\mathrm{aA}$ & 91 & & 80 & & 97 & $\mathrm{aA}$ & 92 & $\mathrm{aA}$ & 95 & $\mathrm{aA}$ & 85 & $\mathrm{aA}$ \\
\hline $\begin{array}{l}\text { Glyphosate + } \\
\text { pyraflufen }\end{array}$ & 44 & $\mathrm{bBC}$ & 59 & $\mathrm{aB}$ & 73 & & 43 & & 60 & $\mathrm{bBC}$ & 82 & $\mathrm{aAB}$ & 63 & $\mathrm{aAB}$ & 78 & $\mathrm{aAB}$ \\
\hline $\begin{array}{l}\text { Glyphosate + } \\
\text { chlorimuron }\end{array}$ & 12 & $\mathrm{aDEF}$ & 17 & $\mathrm{aCD}$ & 2 & & 1 & & 73 & $\mathrm{aAB}$ & 82 & $\mathrm{aAB}$ & 97 & $\mathrm{aA}$ & 72 & $\mathrm{aAB}$ \\
\hline $\begin{array}{l}\text { Untreated- } \\
\text { check }\end{array}$ & 0 & $\mathrm{aF}$ & 0 & $\mathrm{aD}$ & 0 & & 0 & & 0 & $\mathrm{aE}$ & 0 & $\mathrm{aC}$ & 0 & $\mathrm{Ae}$ & 0 & $\mathrm{aD}$ \\
\hline
\end{tabular}

${ }^{1}$ Uppercase letters denote the comparison of herbal treatments within the same phenological stage (column), and lowercase letters denote the comparison of herbal treatments within different phenological stages (row). Means followed by the same letter, either lowercase or uppercase, are not significantly different according to the Tukey test at 0.05 .

28 DAA (Table 6). Increasing doses of 2.4-D amine differed only in the evaluation performed at 28 DAA, where the control observed at the doses of 670 and $1005 \mathrm{~g}$ a.e. $\mathrm{ha}^{-1}$ was lower than that observed with the remaining doses of 2.4-D amine. The combination of glyphosate $+2.4-\mathrm{D}$ amine presented a control of $38 \%$ at $28 \mathrm{DAA}$, whereas the combination of glyphosate + saflufenacil showed greater visual control than the other treatments with a mean control of $60 \%$ in the evaluations performed between 7 and 28 DAA (Table 6).

At 28 DAA, sequential paraquat application was performed. The levels of control increased compared with the treatments that did not receive this sequential application (Table 7) The exceptions were the glyphosate and glyphosate + saflufenacil treatments, for which some evaluations showed no difference, regardless of the presence or absence of paraquat. The greatest increases in control following sequential application were observed in the treatments where the initial application presented lower efficiency. On averaging the control obtained using the treatments, sequential paraquat application increased the control of E. mollis by $44 \%$ compared with isolated application. Following a sequential paraquat application, treatments containing 2,4$\mathrm{D}$ amine presented higher values of visual control based on the evaluation performed at 35 DAA. Plants sprinkled with glyphosate or glyphosate + saflufenacil showed gradual regrowth, reducing the visual weed control to $15 \%$. At the end of the experiment, 50 days after the sequential application (DAS), treatments with 2.4-D amine (1675 g a.e. $\mathrm{ha}^{-1}$ ) and glyphosate $+2.4-\mathrm{D}$ amine, both with sequential paraquat application, presented the highest levels of visual control, with $85 \%$ and $94 \%$, respectively (Table 7).

Low levels of visual control before sequential paraquat application demonstrated the difficulty in controlling E. mollis in the field. Isolated glyphosate application has shown low efficiency in several weeds. Therefore, the use of mixtures enables the spectrum of control to be expanded (RONCHI et al., 2002). The lethal effect of the 2,4$\mathrm{D}$ amine application requires a longer duration to appear compared with other mechanisms of action (SENSEMAN, 2007). This situation would explain the lack of differences in control between the doses of 2.4-D amine in the first evaluations before sequential application (Table 6), with a dose-related 
Table 5 - Parameters of the logistic equation and $\mathrm{C}_{50}, \mathrm{C}_{80}$, and $\mathrm{C}_{95}$ values as a function of visual control (\%) of Elephantopus mollis in response to herbicide application at 14,35 , and 81 days after application (DAA).

\begin{tabular}{|c|c|c|c|c|c|c|c|c|}
\hline Herbicide & Evaluation & $a^{1}$ & $\mathrm{c}^{1}$ & $\mathrm{C}_{50}{ }^{2}$ & Deviation & $\mathrm{C}_{80}{ }^{2}$ & $\mathrm{C}_{95}$ & $\begin{array}{l}\text { Recommended } \\
\text { maximum dose (g } \\
\left.\text { a.i. } \text { ha }^{-1}\right)\end{array}$ \\
\hline \multirow{3}{*}{ Paraquat } & $14 \mathrm{DAA}$ & 98,9 & $-2,43$ & 86,9 & 2,7 & 157,4 & 323,3 & \multirow{3}{*}{400} \\
\hline & $35 \mathrm{DAA}$ & 116,1 & $-0,73$ & 257,1 & 181,6 & 764,7 & 2019,4 & \\
\hline & 81 DAA & 106,0 & $-1,18$ & 265,2 & 35,8 & 687,4 & 1648,4 & \\
\hline \multirow{3}{*}{ Glyphosate } & $14 \mathrm{DAA}$ & 65,1 & $-0,94$ & 14256,2 & 17805,4 & $>85211,3$ & $>48764,3$ & \multirow{3}{*}{$1080^{3}$} \\
\hline & 35 DAA & 32,9 & $-1,36$ & 260,5 & 16,0 & $>384,6$ & $>356,1$ & \\
\hline & $81 \mathrm{DAA}$ & 87,7 & $-1,66$ & 287,4 & 16,4 & $>1177,3$ & $>1348,4$ & \\
\hline \multirow{3}{*}{ 2,4-D amine } & 14 DAA & 106,2 & $-1,42$ & 2198,0 & 370,3 & 4824,2 & 9906,1 & \multirow{3}{*}{$1005^{3}$} \\
\hline & 35 DAA & 119,6 & $-0,84$ & 1494,2 & 335,1 & 3451,2 & 7463,9 & \\
\hline & $81 \mathrm{DAA}$ & 101,5 & $-1,71$ & 295,0 & 29,2 & 636,1 & 1415,8 & \\
\hline \multirow{3}{*}{ Glufosinate } & 14 DAA & 95,7 & $-1,30$ & 96,0 & 13,7 & 335,9 & 4195,2 & \multirow{3}{*}{600} \\
\hline & 35 DAA & 100,9 & $-1,17$ & 124,1 & 19,1 & 390,9 & 1334,4 & \\
\hline & 81 DAA & 102,4 & $-1,46$ & 88,7 & 14,0 & 212,1 & 509,5 & \\
\hline \multirow{3}{*}{ Pyraflufen } & 14 DAA & 97,8 & $-2,02$ & 4,9 & 0,7 & 10,2 & 27,9 & \multirow{3}{*}{10} \\
\hline & 35 DAA & 143,9 & $-0,50$ & 16,7 & 18,8 & 26,2 & 63,0 & \\
\hline & 81 DAA & 130,8 & $-0,70$ & 9,5 & 7,2 & 18,2 & 38,3 & \\
\hline \multirow{3}{*}{$\begin{array}{l}\text { Pyraflufen + } \\
\text { Glyphosate }\end{array}$} & 14 DAA & 110,9 & $-0,78$ & 2,4 & 0,5 & 8,1 & 23,5 & \multirow{3}{*}{10} \\
\hline & 35 DAA & 151,3 & $-0,45$ & 13,1 & 17,6 & 16,9 & 41,9 & \\
\hline & 81 DAA & 106,7 & $-0,83$ & 1,9 & 0,2 & 7,1 & 23,7 & \\
\hline \multirow{3}{*}{ Saflufenacil } & 14 DAA & 103,3 & $-1,20$ & 10,6 & 0,7 & 29,6 & 80,8 & \multirow{3}{*}{35} \\
\hline & 35 DAA & 101,2 & $-1,40$ & 9,40 & 0,20 & 24,3 & 66,0 & \\
\hline & 81 DAA & 103,4 & $-1,20$ & 15,2 & 1,4 & 42,3 & 114,7 & \\
\hline \multirow{3}{*}{$\begin{array}{l}\text { Saflufenacil + } \\
\text { Glyphosate }\end{array}$} & 14 DAA & 97,9 & $-1,96$ & 4,6 & 0,1 & 10,0 & 27,5 & \multirow{3}{*}{35} \\
\hline & 35 DAA & 98,2 & $-1,13$ & 3,3 & 0,7 & 12,2 & 66,3 & \\
\hline & 81 DAA & 102,0 & $-0,97$ & 5,8 & 0,3 & 22,0 & 85,3 & \\
\hline \multirow{3}{*}{ Chlorimuron } & 14 DAA & 6,4 & $-1,10$ & 11,5 & 1,7 & $>12,4$ & $>12,2$ & \multirow{3}{*}{20} \\
\hline & 35 DAA & 60,7 & $-1,70$ & 11,6 & 1,3 & $>26,8$ & $>21,1$ & \\
\hline & 81 DAA & 87,5 & $-1,30$ & 17,0 & 1,3 & $>105,0$ & $>119,8$ & \\
\hline \multirow{3}{*}{$\begin{array}{l}\text { Chlorimuron + } \\
\text { Glyphosate }\end{array}$} & 14 DAA & 48,1 & $-1,10$ & 28,4 & 5,6 & $>65,5$ & $>54,0$ & \multirow{3}{*}{20} \\
\hline & $35 \mathrm{DAA}$ & 60,6 & $-0,75$ & 11,9 & 3,4 & $>78,7$ & $>46,1$ & \\
\hline & $81 \mathrm{DAA}$ & 100,5 & $-0,90$ & 7,0 & 1,1 & 31,8 & 165,9 & \\
\hline
\end{tabular}

${ }^{1} \mathrm{a}=$ amplitude between the maximum and minimum point of the variable; $\mathrm{c}=$ slope of the curve around $\mathrm{C}_{50} .{ }^{2} \mathrm{C}_{50}, \mathrm{C}_{80}$, and $\mathrm{C}_{95}=\mathrm{dose}$ required for $50 \%, 80 \%$, and $95 \%$ control, respectively. ${ }^{3} \mathrm{~g}$ a.e. $\mathrm{ha}^{-1}$.

differentiation only occurring in the evaluation performed at 28 DAA. The combination of the herbicide 2,4-D amine and glyphosate improves weed control. Plants sprinkled with 2,4-D amine showed little re-growth capacity compared with those that received the other treatments. The high translocation capacity of 2,4-D amine and its mechanism of action in the weed can limit re-growth, rendering this herbicide fundamental for controlling this weed in agricultural production systems.

The devised glyphosate $+2.4-\mathrm{D}$ amine mixture was efficient in the control of Convolvulus arvensis in wheat production areas (STONE et al., 2005) and Conyza canadensis during the winter period in the southern United States of America (WIESE et al., 1995). Control of the weed Artemisia verlotorum, 
Table 6 - Visual control (\%) of Elephantopus mollis at 7, 14, 21, and 28 days after application (DAA) as a function of spraying herbicides in the field experiment.

\begin{tabular}{|c|c|c|c|c|c|c|c|c|c|}
\hline \multirow{2}{*}{$\begin{array}{l}\text { Herbicide } \\
\text { Glyphosate }\end{array}$} & \multirow{2}{*}{$\begin{array}{c}\text { g a.e. ha }{ }^{-1} \\
1080\end{array}$} & \multicolumn{2}{|c|}{-----7 DAA----- } & \multicolumn{2}{|c|}{-----14 DAA---- } & \multicolumn{2}{|c|}{----21 DAA---- } & \multicolumn{2}{|c|}{-----28 DAA----- } \\
\hline & & 2 & $\mathrm{c}^{2}$ & 9 & $\mathrm{~d}$ & 8 & $\mathrm{c}$ & 16 & d \\
\hline 2,4-D amine & 670 & 19 & $\mathrm{~b}$ & 12 & $\mathrm{~cd}$ & 10 & bc & 19 & d \\
\hline 2,4-D amine & 1005 & 15 & $\mathrm{~b}$ & 14 & $\mathrm{~cd}$ & 11 & $\mathrm{bc}$ & 24 & $\mathrm{~cd}$ \\
\hline 2,4-D amine & 1340 & 22 & $\mathrm{~b}$ & 18 & $\mathrm{bc}$ & 12 & $\mathrm{bc}$ & 30 & $\mathrm{bc}$ \\
\hline 2,4-D amine & 1675 & 24 & $\mathrm{~b}$ & 19 & bc & 16 & $\mathrm{~b}$ & 35 & $\mathrm{~b}$ \\
\hline Glyphosate $+2,4-\mathrm{D}$ amine & $1080+1340$ & 21 & $\mathrm{~b}$ & 24 & $\mathrm{~b}$ & 18 & $\mathrm{~b}$ & 38 & $\mathrm{~b}$ \\
\hline Glyphosate + saflufenacil & $1080+35^{1}$ & 60 & $\mathrm{a}$ & 58 & a & 61 & a & 60 & a \\
\hline Untreated-check & -- & 0 & $\mathrm{c}$ & 0 & e & 0 & $\mathrm{~d}$ & 0 & e \\
\hline
\end{tabular}

${ }^{1} \mathrm{~g}$ a.i. ha ${ }^{-1} .{ }^{2}$ Means followed by the same letter in the columns are not significantly different according to the Tukey test at 0.05 .

which, similar to E. mollis exhibits high re-growth capacity, was efficient using increasing doses of glyphosate + 2.4-D amine mixture (BRIGHENTI et al., 1994). Therefore, under the conditions in which the experiment was performed, the best control level of E. mollis was obtained using the glyphosate + 2.4-D amine application, followed by sequential paraquat application. Considering the possible ban of paraquat in Brazil in 2020 (ANVISA, 2017), the herbicide glufosinate and herbicides that inhibit the

Table 7 - Visual control (\%) of Elephantopus mollis at 7, 21, 35, and 50 days after application (DAA) as a function of the interaction between herbicides and the presence or absence of sequential paraquat application in the field experiment.

\begin{tabular}{|c|c|c|c|c|c|c|c|c|c|c|c|c|c|c|c|c|c|}
\hline \multirow{3}{*}{$\begin{array}{l}\text { Treatment } \\
\text { Glyphosate } \\
\text { (Gly) }\end{array}$} & \multirow{3}{*}{$\begin{array}{c}\text { g a.e. } \mathrm{ha}^{-1} \\
1080\end{array}$} & \multicolumn{4}{|c|}{---Paraquat (7 DAA)--- } & \multicolumn{4}{|c|}{---Paraquat (21 DAA)--- } & \multicolumn{4}{|c|}{---Paraquat (35 DAA)--- } & \multicolumn{4}{|c|}{--Paraquat (50 DAA)-- } \\
\hline & & \multicolumn{2}{|c|}{ Absence } & \multicolumn{2}{|c|}{ Presence } & \multicolumn{2}{|c|}{ Absence } & \multicolumn{2}{|c|}{ Presence } & \multicolumn{2}{|c|}{ Absence } & \multicolumn{2}{|c|}{ Presence } & \multicolumn{2}{|c|}{ Absence } & \multicolumn{2}{|c|}{ Presence } \\
\hline & & 15 & $\mathrm{bC}^{2}$ & 59 & $\mathrm{aB}$ & 5 & $\mathrm{aAB}$ & 15 & $\mathrm{aDE}$ & 6 & $\mathrm{bCD}$ & 22 & $\mathrm{aD}$ & 10 & $\mathrm{aC}$ & 15 & $\mathrm{aE}$ \\
\hline $\begin{array}{l}2,4-\mathrm{D} \\
\text { amine }\end{array}$ & 670 & 27 & bB & 76 & $\mathrm{aAB}$ & 10 & $\mathrm{bAB}$ & 26 & $\mathrm{aCDE}$ & 14 & $\mathrm{bBCD}$ & 47 & $\mathrm{aC}$ & 30 & $\mathrm{bB}$ & 49 & $\mathrm{aD}$ \\
\hline $\begin{array}{l}2,4-\mathrm{D} \\
\text { amine }\end{array}$ & 1005 & 32 & $\mathrm{bAB}$ & 66 & $\mathrm{aAB}$ & 12 & $\mathrm{bAB}$ & 34 & $\mathrm{aBCD}$ & 24 & $\mathrm{bAB}$ & 51 & $\mathrm{aBC}$ & 35 & $\mathrm{bAB}$ & 65 & $\mathrm{aC}$ \\
\hline $\begin{array}{l}2,4-\mathrm{D} \\
\text { amine }\end{array}$ & 1340 & 35 & $\mathrm{bAB}$ & 74 & $\mathrm{aAB}$ & 21 & $\mathrm{bAB}$ & 58 & $\mathrm{aAB}$ & 25 & $\mathrm{bAB}$ & 62 & $\mathrm{aBC}$ & 40 & $\mathrm{bAB}$ & 80 & $\mathrm{aB}$ \\
\hline $\begin{array}{l}2,4-\mathrm{D} \\
\text { amine }\end{array}$ & 1675 & 39 & $\mathrm{bAB}$ & 68 & $\mathrm{aAB}$ & 18 & $\mathrm{bAB}$ & 41 & $\mathrm{aABC}$ & 22 & $\mathrm{bABC}$ & 68 & $\mathrm{aAB}$ & 39 & $\mathrm{bAB}$ & 85 & $\begin{array}{c}\mathrm{aA} \\
\mathrm{B}\end{array}$ \\
\hline $\begin{array}{l}\text { Gly }+2,4-\mathrm{D} \\
\text { amine }\end{array}$ & $\begin{array}{c}1080+ \\
1340\end{array}$ & 40 & $\mathrm{bAB}$ & 80 & $\mathrm{aA}$ & 26 & $\mathrm{bA}$ & 65 & $\mathrm{aA}$ & 35 & $\mathrm{bA}$ & 84 & $\mathrm{aA}$ & 44 & $\mathrm{bA}$ & 94 & $\mathrm{aA}$ \\
\hline $\begin{array}{l}\text { Gly } \quad+ \\
\text { saflufenacil }\end{array}$ & $\begin{array}{c}1080+ \\
35^{1}\end{array}$ & 46 & $\mathrm{bA}$ & 78 & $\mathrm{aAB}$ & 8 & $\mathrm{aAB}$ & 15 & $\mathrm{aDE}$ & 6 & $\mathrm{aCD}$ & 15 & $\mathrm{aD}$ & 6 & $\mathrm{bC}$ & 14 & $\mathrm{aE}$ \\
\hline $\begin{array}{l}\text { Untreated } \\
\text { (control) }\end{array}$ & -- & 0 & $\mathrm{bD}$ & 60 & $\mathrm{aB}$ & 0 & $\mathrm{aB}$ & 9 & $\mathrm{aE}$ & 0 & $\mathrm{aD}$ & 9 & $\mathrm{aD}$ & 0 & $\mathrm{bC}$ & 12 & $\mathrm{aE}$ \\
\hline
\end{tabular}

${ }^{1} \mathrm{~g}$ a.i. $\mathrm{ha}^{-1}$

${ }^{2}$ Uppercase letters denote the comparison of herbicide treatments having the same type of sequential paraquat application (presence or absence; column), and lowercase letters denote the comparison of herbicide treatments having the same type of sequential paraquat application (presence or absence; row). Means followed by the same letter, either lowercase or uppercase, are not significantly different according to the Tukey test at 0.05 .

Ciência Rural, v.51, n.9, 2021. 
enzyme PROTOX may be promising substitutes for sequential application.

\section{CONCLUSION}

For most herbicides tested, E. mollis plants from lawn areas presented greater sensitivity to herbicides compared with those from agricultural areas. There was a similarity in the control levels between the vegetative and reproductive phases for most herbicides and doses used in this study. Among the isolated herbicide applications, glufosinate and 2,4-D amine were the most effective ones for controlling E. mollis. The glyphosate $+2,4-\mathrm{D}$ amine mixture application, followed by sequential paraquat application presented high control of E. mollis.

\section{DECLARATION OF CONFLICT OF INTEREST}

The authors declare no conflict of interest. The funding sponsors had no role in the design of the study; in the collection, analysis, or interpretation of data; in the writing of the manuscript, and in the decision to publish the results.

\section{AUTHORS' CONTRIBUTIONS}

All authors conceived and designed experiments ALN and BC performed the experiments and statistical analyses of experimental data. All authors prepared the draft of the manuscript. All authors critically revised the manuscript and approved of the final version.

\section{REFERENCES}

ANVISA. Voto $\mathrm{N}^{\mathrm{o}}$ 056/2017/DIREG/ANVISA. Processo $\mathbf{n}^{0}$ 25351.056773/2013-21. D. D. R. Sanitária. Brasília: ANVISA. Expediente $\mathrm{n}^{\circ}$ 0080490/13-8: 22 p. 2017.

BALBINOT, Andrisa. Elephantopus mollis Kunth (Asteraceae): emergency flow and herbicides dose-response curves. 2016. $71 \mathrm{f}$. Dissertação (Mestrado em Ciências Biológicas) - Universidade Federal de Santa Maria, Santa Maria, 2016.

BARNES, E.R., et al. Common ragweed (Ambrosia artemisiifolia L.) nterference with soybean in Nebraska. Agronomy Journal, v.110, n.2, p.646-653. 2018. Available from: < https://agronomy. unl.edu/Jhala/publications/2018/Common-ragweed-Ambrosiaartemisiifolia-L-interference-with-soybean-Nebraska Barnes-etal. pdf>. Accessed: Jan. 22, 2019. doi: 10.2134/agronj2017.09.0554.

BRIGHENTI, A.M., et al. Controle químico da losna em plantio direto de trigo. Planta Daninha, v.12, p.03-08. 1994. Available from: $\quad<$ http://www.scielo.br/pdf/pd/v12n1/a01v12n1.pdf $>$. Accessed: Jan. 28, 2019. doi: 10.1590/s0100-83581994000100001.

BUNWONG, S., et al. Revisions and key to the Vernonieae (Compositae) of Thailand. Phytokeys, v.37, p.25-101. 2014 Available from: <https://phytokeys.pensoft.net/article/1525/>. Accessed: Jan. 23, 2019. doi: 10.3897/phytokeys.37.6499.
CARVALHO, S.J.P., et al. Curvas de dose-resposta para avaliação do controle de fluxos de emergência de plantas daninhas pelo herbicida imazapic. Planta Daninha, v.23, p.535-542. 2005. Available from: <http://www.scielo.br/pdf/pd/v23n3/ a18v23n3.pdf>. Accessed: Jan. 23, 2019. doi: 10.1590/s010083582005000300018 .

FIGUEIREDO, M.R. A. Interações entre os herbicidas 2,4D e glifosato: aspectos químicos, bioquímicos e fisiológicos. 2015. Dissertação (Mestrado em Fitotecnia) - Escola Superior de Agricultura Luiz de Queiroz, Universidade de São Paulo, Piracicaba, 2015. doi:10.11606/D.11.2015.tde-04052015-092942. Accessed: Jan. 22, 2019: 2019-05-15.

FRANCISCO, F., et al. Maturation, processing and seed storage of Elephantopus mollis Kunth. Acta Scientiarum-Agronomy, v.41. 2019. Available from: <http://www.scielo.br/pdf/asagr/ v41/1807-8621-asagr-41-e42628.pdf >. Accessed: May, 05, 2019. doi: 10.4025/actasciagron.v41i1.42628.

OLIVEIRA JUNIOR, R.S.D., et al. Biologia e manejo de plantas daninhas. Curitiba: Omnipax. 2011. 348 p.

RONCHI, C.P., et al. Misturas de herbicidas para o controle de plantas daninhas do gênero Commelina. Planta Daninha, v.20, p.311-318. 2002. Available from: <http:// www.scielo.br/scielo.php? script $=$ sci_arttext\&pid $=\mathrm{S} 0100$ 83582002000200018\&nrm=iso $>$. Accessed: Jan. 29, 2019. doi: $10.1590 / \mathrm{s} 0100-83582002000200018$.

SENSEMAN, S.A. Herbicide handbook. Lawrence: Weed Science Society of America, v.1. 2007. 458 p.

STONE, A.E., et al. Efficacy and acceptance of herbicides applied for field bindweed (Convulvulus arvensis) control. Weed Technology, v.19, n.1, p.148-153. 2005. Available from: $<$ https://www.jstor.org/stable/3989125?seq=1\#page_scan_tab contents $>$. Accessed: Jan. 22, 2019: 2012/12/04. doi: 10.1614/ wt-04-044r2.

STREIBIG, J.C. Herbicide bioassay. Weed Research, v.28, n.6, p.479-484. 1988. Available from: <https://onlinelibrary.wiley.com/ doi/abs/10.1111/j.1365-3180.1988.tb00831.x>. Accessed: Jan. 22, 2019. doi: 10.1111/j.1365-3180.1988.tb00831.x.

WIESE, A.F., et al. Downy brome (Bromus tectorum), jointed goatgrass (Aegilops cylindrica) and horseweed (Conyza canadensis) control in fallow. Weed Technology, v.9, n.2, p.249-254. 1995. Available from: <https://www.cambridge.org/ core/article/downy-brome-bromus-tectorum-jointed-goatgrassaegilops-cylindrica-and-horseweed-conyza-canadensis-controlin-fallow/0630495CB218200D9108E004D9747467>. Accessed: Feb. 12, 2019. doi: 10.1017/s0890037x00023290.

WU, Z.N., et al. Sesquiterpene lactones from Elephantopus mollis and their anti-inflammatory activities. Phytochemistry, v.137, n.1, p.81-86. 2017. Available from: <https://wwwsciencedirect.ez348.periodicos.capes.gov.br/science/article/pii/ S0031942217300389?via\%3Dihub>. Accessed: Jan. 22, 2019. doi: 10.1016/j.phytochem.2017.01.020

YU, Q., et al. Enhanced rates of herbicide metabolism in low herbicide-dose selected resistant Lolium rigidum. Plant Cell Environ, v.36, n.4, p.818-27. 2013. Available from: <https:// onlinelibrary.wiley.com/doi/pdf/10.1111/pce.12017>. Accessed: Feb. 04, 2019. doi: 10.1111/pce.12017.

Ciência Rural, v.51, n.9, 2021. 